This PDF is a selection from an out-of-print volume from the National Bureau of Economic Research

Volume Title: The Rate and Direction of Inventive Activity: Economic and Social Factors

Volume Author/Editor: Universities-National Bureau Committee for Economic Research, Committee on Economic Growth of the Social Science Research Council

Volume Publisher: Princeton University Press

Volume ISBN: 0-87014-304-2

Volume URL: http://www.nber.org/books/univ62-1

Publication Date: 1962

Chapter Title: Inventive Activity: Government Controls and the Legal Environment

Chapter Author: Jesse W. Markham

Chapter URL: http://www.nber.org/chapters/c2143

Chapter pages in book: (p. $587-608)$ 


\title{
Inventive Activity: Government Controls and the Legal Environment
}

\author{
JESSE W. MARKHAM \\ PRINCETON UNIVERSITY
}

\section{Introduction}

INVENTIVE activity, perhaps more than any other single economic endeavor, mirrors our "mixed" economy. The government has assumed primary responsibility for research relating to the Navy since 1789, and for research in agriculture since the creation of the Department of Agriculture and the land-grant college system in $1862 .{ }^{1}$ It has participated directly in the design of weapons, surface craft, aircraft, missiles and rockets, in the development and control of atomic energy, radio and telecommunications, and in the promotion of science and public health. Except for these areas, and perhaps a few additional ones, control of inventive activity traditionally has been left to a system of private incentives which the government affects only indirectly through the institutions of public law.

An assessment of the impact of government controls and the legal environment on inventive activity in the United States requires, therefore, at the outset a systematic classification of such activity according to the prevailing direct and indirect means of public control (Table 1). From such a classification it immediately becomes clear that inventive activity is subject to a wide variety of controls, and that these controls vary greatly according to type and source of inventive activity.

Research financed and performed directly by the government is subject to the system of political controls applicable to budget items generally. The total sums expended are therefore determined by what the President proposes and Congress approves, and in turn by how serious each considers the "present need" to be. For example, in the decade preceding World War II the federal government spent on the average less than $\$ 40$ million per year on research and development; the annual average for $1941-45$ was $\$ 500$ million, ${ }^{2}$ reflecting

\footnotetext{
${ }^{1}$ The federal government had assumed responsibility for disscmination of plants, seeds, and certain information relating to agriculture as early as 1839 .

${ }^{2}$ Science and Public Policy, the President's Scientific Research Board, 1947, Vol. 1, p. 10.
} 
TABLE 1

Classification of InVentive Activity according to

Means of Public Control

\begin{tabular}{|c|c|}
\hline Inventive Activity & Means of Public Control \\
\hline \multicolumn{2}{|c|}{ GOVERNMENT } \\
\hline Direct research & Budgetary process \\
\hline $\begin{array}{l}\text { Research contracted to the private } \\
\text { sector }\end{array}$ & $\begin{array}{l}\text { Budgetary process and patent, antitrust } \\
\text { and taxation laws }\end{array}$ \\
\hline Support of scientific education & $\begin{array}{l}\text { Budgetary process and educational } \\
\text { institution policy }\end{array}$ \\
\hline \multicolumn{2}{|c|}{ PRIVATE INDIVIDUALS AND BUSINESS FIRMS } \\
\hline Self-financed research & Patent, antitrust and taxation laws \\
\hline Financed under government contract & $\begin{array}{l}\text { Budgetary process and patent, antitrust } \\
\text { and taxation laws }\end{array}$ \\
\hline $\begin{array}{l}\text { Research contracts with and donations to } \\
\text { educational institutions and nonprofit } \\
\text { organizations }\end{array}$ & $\begin{array}{l}\text { Educational institution policy and tax } \\
\text { laws }\end{array}$ \\
\hline \multicolumn{2}{|c|}{ EDUCATIONAL AND NONPROFIT INSTITUTIONS } \\
\hline Self-financed & Educational institution policy. \\
\hline Government financed & $\begin{array}{l}\text { Budgetary process and educational } \\
\text { institution policy }\end{array}$ \\
\hline Business financed & $\begin{array}{l}\text { Educational institution policy and tax } \\
\text { laws }\end{array}$ \\
\hline
\end{tabular}

the need for massive military research. The federal government in the pre-Sputnik years $1952-57$ spent on the average $\$ 76$ million per year on space exploration and flight technology. The 1960 fiscal year budget called for expenditures of $\$ 325$ million and the proposed 1961 budget, the first to follow the Soviet Union's successful lunar probe, called for $\$ 600$ million. ${ }^{3}$ These figures serve only to emphasize the point that the level of government supported inventive activity is determined as much by the forces of politics as it is by "pure" economic considerations. This is true not only because the dollar magnitude of specific items in the federal budget must be politically acceptable, but also because research and development expenditures for such purposes as defense, space exploration, public health, and so on, are not readily determinable by marginal social cost-marginal social benefit analysis. It is impossible even to measure in terms of current dollars the marginal cost to society of a given increase in taxes, much less the marginal social benefit of a successful flight to the moon in 1962 as compared with 1965.

\footnotetext{
${ }^{3}$ President Eisenhower's Budget Message to Congress, January 18, 1960, as reproduced in the New York Times, January 19, 1960, p. 17.
} 
Government research contracted to private firms is also controlled primarily by the budgetary process, although such aspects of the legal environment as the patent, antitrust, and taxation laws are not totally inapplicable. Government research contracts sometimes specify that patentable discoveries made in the course of such research belong to the government, and hence are not patentable by the contracting firms. Some contracts permit firms to patent but provide that the government may obtain royalty-free licenses. ${ }^{4}$ In either case the patent incentive is somewhat weakened. But, as Usher has persuasively argued, any achievement of large social importance involves the cumulative synthesis of several strategic inventions. ${ }^{5}$ The prohibition, or the provision for royalty-free licensing to the government, applies to the contracted research but not to the subsequent synthesis which may produce a patentable invention. Similarly, while the antitrust laws may not be directly applicable to research performed under a particular government contract, the distribution of prime contracts by size of firm and the effect the research may have on the future market position of the contracting firm raise antitrust considerations. The effect the corporate income tax has on such research is not readily discernible but will depend, among other factors, on the contracting firm's current profit position and on whether it would have engaged in similar research activities on its own.

Government research contracted to educational and other nonprofit organizations is controlled by the budgetary process and the policies of the recipient institutions. In the case of universities such policies usually relate to the issues of academic freedom, the compatibility of the contract research with the university's overall research program, the special research interests of the scientists involved, and so on.

Research expenditures for inventive activity conducted by private firms (and individuals) are governed by the profit motive subject to incentives and constraints that inhere in the legal environment. The patent laws, which are essentially a means for making new knowledge public in exchange for a 17-year right to monopolize the use of an invention, are designed to serve as a stimulus; they provide the inventor with an alternative to secrecy, an alternative he would not have in

${ }^{4}$ Cf. Gayle Parker, "Comparison of the Patent Provisions of the NASA Act and AEC Act," Patent, Trademark, and Copyright Journal of Research and Education, Fall 1959, pp. 303-316.

${ }^{5}$ Abbott P. Usher, A History of Mechanical Inventions, rev, ed., Harvard University. Press, 1954, pp. 68-69. 
their absence. Presumably the corporate income tax serves both as an incentive and as a constraint. Corporations, because they are permitted to expense rather than capitalize research expenditures, may with some justification reason that each dollar spent on research reduces profits after taxes by only $\$ 0.48 .{ }^{6}$ On the other hand, the income tax significantly reduces what Schumpeter has called the pool of uncommitted retained earnings which corporations may use for new and untried ventures. It can be said that, on balance, the corporate income tax acts as an incentive if an increase of $\$ 1.00$ in after-tax profits would lead to new expenditures on research of less than $\$ 0.48$, and as a constraint if more than $\$ 0.48$. A similar line of reasoning applies to corporate donations to universities and other nonprofit institutions for research purposes. The impact of the antitrust laws, the complexity of which defies the brevity an introductory statement imposes, is generally supposed to be favorable to inventive activity on the ground that it stimulates competitive effort, which often takes the form of an innovational race against competitors.

Of the three principal seats of research activity given attention in this study the educational and nonprofit institutions are the least affected by economic, political, and legal controls. They are by definition nonprofit organizations and for this reason are liberated from profits maximizing incentives. While both scientist and institution have patented certain of their inventions, patentability is not an important consideration in the conduct of their research. A few, but probably only a few, are affected by political criteria of the sort that determine the research items in the federal government's budget. They are unaffected by the antitrust laws and, although they may be favorably affected by income tax regulations, they are not guided in their research to any considerable extent by tax considerations. Even in their conduct of research under government contract such institutions generally have held out for a minimum of contractual constraints. ${ }^{?}$ This relative freedom from control is, from an analytical point of view, not an unmixed blessing. Because nonprofit institutions are free to pursue within very broad limits whatever research they wish, what they in fact will pursue is highly unpredictable. They are susceptible

\footnotetext{
${ }^{6}$ It has been argued that such expenditures should be capitalized. $c f$. National Science Foundation, Proceedings of a Conference on Research and Development and Its Impact on the Economy, 1958, p. 122.

' Some universities have voiced apprehension over the increasing amount of contract research and the limitations it imposes on the freedom of individual research scientists. See Harold W. Dodds on "Projectitis" in Official Register of Princeton University: The President's Report, 1952-53, January 1, 1954, pp. 19-24.
} 
to neither political nor economic analysis since they presumably are motivated by neither political nor economic incentives.

In sum, inventive activity in the United States is affected by a wide variety of incentives and legal institutions. The array of incentives includes what the government considers to be in the public interest and politically feasible, the profit motive, the quest for knowledge, the urge to create, and pure humanitarianism. Institutions that act to constrain or release these motives include the budgetary process, the patent system, the income tax laws, the antitrust laws, and what may be loosely defined as the policies of educational and other nonprofit institutions.

\section{Quantitative Importance of Incentives and Controls}

By historical coincidence estimates of advertising and of research and development outlays both reached the $\$ 10$ billion mark in 1957 . Data on advertising are voluminous; those on research and development-though technological change is the principal source of the American economy's sustained increase in productivity ${ }^{8}$ - are intolerably inadequate. In part the problem is one of coverage: all surveys exclude individual inventors, and most exclude small firms. In part it is one of definition: a thin line separates technical effort from technical effort to create. As Dexter Keezer has put it, when Joe fixes a tractor it is repair; if he fails to fix it it is research. ${ }^{9}$ Even references to federal government research outlays do not always distinguish between funds obligated and funds expended, or between calendar and fiscal years. And data from different sources, even from the same source, are not easily reconciled. ${ }^{10}$

But in spite of these inadequacies the data unmistakably show significant shifts in the relative importance of the various financial sources of inventive activity, and hence in the various means of social control (Table 2). In 1930 industry accounted for 70 per cent of total research and development expenditures, nonprofit institutions (mainly universities) for 16 per cent, and the federal government for only 14 per cent. In 1959 the federal government financed 60 per cent of total

${ }^{8}$ Some estimates of the contribution technological change has made to productivity run as high as 87 per cent. See Robert M. Solow, "Technological Change and the Aggregate Production Function," Review of Economics and Statistics, August 1957, pp. 312-320. Those who think this estimate too high generally consider technological change to be the most important single factor. See Richard Nelson, "The Economics of Invention: A Survey of the Literature," Journal of Business, April 1959, p. 102.

' National Science foundation, op. cit., p. 146.

${ }^{10}$ See note to Table 2. 
TABLE 2

Research and Development Expenditures by Government, Industry, and NonProfit Institutions, Selected Years, 1930-59 (millions of dollars)

\begin{tabular}{|c|c|c|c|c|c|}
\hline Source and Nature of Expenditure & 1930 & $\begin{array}{l}1941-45 \\
\text { average }\end{array}$ & 1953 & 1956 & 1959 \\
\hline Government & 23 & 500 & 2,810 & 5,234 & 7,200 \\
\hline Research performed in government & n.a. & n.a. & 970 & 1,400 & 1,600 \\
\hline Research contracted to private sector & n.a. & n.a. & 1,840 & 3,834 & 5,600 \\
\hline Industry & n.a. & n.a. & 1,500 & 3,134 & 4,600 \\
\hline University & n.a. & n.a. & 340 & 700 & 1,000 \\
\hline Other & n.a. & n.a. & & & \\
\hline Business firms & 116 & 80 & 3,870 & 6,000 & 9,100 \\
\hline Self-financed & n.a. & n.a. & 2,370 & 2,900 & 4,500 \\
\hline Government financed & n.a. & n.a. & 1,500 & 3,134 & 4,600 \\
\hline Donations to nonprofit institutions & n.a. & n.a. & 10 & - & 一 \\
\hline \multicolumn{6}{|l|}{ Educational and other nonprofit institutions } \\
\hline $\begin{array}{l}\text { University } \\
\text { Other }\end{array}$ & 20 & $10\}$ & 530 & 1,000 & 1,300 \\
\hline Self-financed & n.a. & n.a. & 180 & 300 & 300 \\
\hline Government f & n.a. & n.a. & 340 & 700 & 1,000 \\
\hline Business financed and other sources & n.a. & n.a. & 10 & n.a. & n.a. \\
\hline Totals (duplications eliminated) & 166 & 600 & 5,400 & 9,000 & 12,000 \\
\hline
\end{tabular}

Source: National Science Foundation, Proceedings of a Conference on Research and Development and its Impact on the Economy, 1958, pp. 170-178; Science and Public Policy, a Report to the President by John R. Steelman, Chairman, Pressideñt's Scientific Research Board, 1947, Vol. I, p. 10; Business Plans, 1956-1959, Prepared by the McGraw-Hill Department of Economics, New York, McGraw Hill, 1956, p. 13; and Dexter M. Keezer, Douglas Greenwald, and Robert P. Ulin, "The Outlook for Expenditures on Research and Development During the Next Decade," American Economic Review, May 1960, p. 355. Where estimates varied, as they usually did, the most recent compilation was used.

${ }^{a}$ Includes state government.

n.a. $=$ Not available.

research and development expenditures, industry 38 per cent, and nonprofit institutions less than 3 per cent. A corresponding shift has occurred in the relative importance of the instruments of control over the private and public sectors of the economy. In 1930 and up to the outbreak of World War II, approximately 70 per cent of all inventive activity occurred in industry, which nominally was subject to the profit motive and the patent and antitrust laws; in recent years this share has been reduced to less than 40 per cent. Meanwhile, the share controlled by federal budgetary considerations had risen by 1959 from 14 per cent to 60 per cent. In decisions concerned with the financing of inventive activity, therefore, political feasibility and what 
the government considers to be the public need have become the principal instruments of control, replacing private profit incentives and the traditional legal instruments of antitrust laws and the patent system.

No similar shift has occurred in research and development performance. In 1953 private industry performed 72 per cent of all inventive activity as measured by research and development funds expended, the federal government 12 per cent, and nonprofit institutions, such as universities, 10 per cent. In 1956 industry performed 70 per cent, and in 195976 per cent. This pattern of performance does not differ significantly from that of the thirties. Data on inventive activity, like that on corporate ownership, reveal what may be called the "Berle and Means effect"-a divorcement of control over research finance and research performance.

The sharp difference in the pattern of research performance and research financing is explained by the pronounced increase in federal government research appropriations and the use of such funds to support research in the private sector of the economy. In 1959 the government contracted 78 per cent of its total appropriations for research and development out to the private sector-64 per cent to industry and 14 per cent to nonprofit institutions. These contracted funds accounted for 51 per cent of the total inventive activity performed by industry and for 77 per cent of that performed by nonprofit institutions.

The impact of government-supported research is spread far from evenly throughout American industry. For the total research and development performed by industry and financed by government in 1956, 58 per cent of the funds went for aircraft and parts, 23 per cent for electrical equipment, 8 per cent for machinery, and 3 per cent for professional and scientific instruments. The four industries alone accounted for 92 per cent of the total research and development funds supplied by government to industry. Telecommunications and broadcasting accounted for an additional 2 per cent. In these five industries, all of which are vitally tied up with the Nation's defense effort, government sponsored research accounts for from 40 per cent to nearly 90 per cent of total research expenditures. The remaining 6 per cent of government-sponsored research in industry-federal funds of $\$ 136$ million-appears to be spread thinly and evenly over the rest of the private sector of the economy. 
One side effect of these developments deserves emphasis. Throughout the 1930's universities accounted for slightly less than 25 per cent of all research expenditures. Since it is generally agreed that during this period universities were primarily preoccupied with basic research, and that government and business made only a modest contribution at that level, it seems reasonable to conclude that basic research accounted for something in excess of one-quarter of total research expenditures. In 1953 basic research expenditures amounted to $\$ 435$ million, ${ }^{11}$ more than was spent on all types of research in the 1930's but still only 8 per cent of total research expenditures in 1953. Relative to total research, therefore, basic research has declined. And the sources of funds for basic research, as in the case of total research, have on an increasing scale become divorced from the locus of research performance. In 1953 the federal government financed 36 per cent but performed only 11 per cent of all basic research; colleges and universities financed only 14 per cent but performed slightly more than 47 per cent; other nonprofit institutions financed about 9 per cent and performed 3 per cent; and industry financed 41 per cent and performed slightly less than 39 per cent. ${ }^{12}$ Only in industry, which performs less than two-fifths of the total, is the decision to engage in basic research tied directly to the decision to finance it.

What effect have these recent trends had on the traditional incentives for, and instruments of control over, inventive activity? The data strongly suggest that they play a relatively less important role in the inventive process than they formerly did. Even if we make some allowance for the possibility that industry takes on a portion of the government financed research with an eye toward increasing its patent holdings and profits in the distant future, it can still be reasonably concluded that the traditional incentives and institutional controls governing inventive activity have given considerable ground to the political, welfare, and defense (the three are not mutually exclusive) considerations which come into play in the federal budgetary process.

It does not follow from this, of course, that approximately twofifths of all research outlays are prompted by commercial incentives and governed by the patent system and the antitrust laws. The above

${ }_{11}$ National Science Foundation, op. cit., p. 171.

12 Ibid. These data probably understate the extent of divorcement. Industry receives substantial sums for basic research from the federal government and supplies substantial sums to universities and other nonprofit organizations. The gross difference between basic research financed and basic research performed by industry would be considerably greater than the net difference. 
data omit altogether the activity of the free-lance inventor. While his contribution to total inventive effort has unquestionably undergone a relative decline over the past half-century, ${ }^{13}$ there are no grounds for writing it off as insignificant. ${ }^{14}$ And, as pointed out earlier, research financed by government but performed by industry may not be completely divorced from the traditional incentives and instruments of public control. Finally, a significant portion of the research financed by industry would probably be carried on in the absence of patent protection. The eleventh annual McGraw-Hill survey of 1956 showed that about 50 per cent of all reporting companies were conducting research on new products, 41 per cent were conducting research on product improvement, and only 11 per cent reported research on new processes. ${ }^{15}$ Research on new products and processes may be motivated by patentability, but the bulk of the research on product improvement probably reflects the exertion of competitive effort to keep abreast or move ahead of rivals in established markets. Such research effort is a normal aspect of product competition, much of which is carried on without the incentives afforded by the patent system. ${ }^{16}$ If we were to make the rather heroic assumption that such competitive research just about offset the unreported research carried on by free-lance inventors, and the further assumption that the patent system had a negligible effect on industry research financed by government, it could be concluded that the patent and antitrust laws were applicable to approximately two-fifths of all inventive activity. ${ }^{17}$ Since there are no satisfactory means for testing the validity of either assumption, the soundest conclusion is that in recent years no more than one-

${ }^{13}$ Evidence of the relative decline in the role of what is romantically referred to as the attic inventor is found in patent assignments. According to data supplied by $\mathbf{P}$. J. Frederico of the United States Patent Office, in 1900 over 80 per cent of all patents issued were assigned directly to individuals and less than 20 per cent to corporations; in 1955 about 39 per cent were assigned to individuals, 59 per cent to corporations, and slightly over 2 per cent to the government.

${ }^{14}$ The press frequently reports inventions patented by individuals. See report on new carbonated beverage bottle cap patented in January 1960 by Clyde A. Tolson, top aid to J. Edgar Hoover, New York Times, January 23, 1960, p. 26.

${ }^{15}$ National Science Foundation, op. cit., p. 123.

${ }^{16}$ A. F. Ravenshear drew this distinction between "intensive inventions" (that lower the costs of existing goods) and "originative inventions" (that produce a new result) more than a half-century ago, and concluded that the former did not require the patent incentive. See his The Industrial and Commercial Influence of the English Patent System, London, 1908, pp. 52-55.

${ }^{17}$ It can be assumed with some justification that free-lance inventors are affected by the patent system but not the antitrust laws, that the normal product-improving research of industrial firms is affected by the antitrust laws but not the patent system, and that both are motivated primarily by commercial incentives. 
quarter to one-half of total inventive activity in the United States is governed by the profit incentive and the traditional means of public control as embodied in patent and antitrust policies; $;{ }^{18}$ until two decades ago the share so governed was significantly greater, probably as much as three-quarters to four-fifths.

These major shifts in the sources of financial support for inventive activity, and the corresponding shifts in relative importance of the instruments of public control, appear to be more or less permanent. The McGraw-Hill forecast for 1969 estimates that government will finance 56 per cent of total research and development costs, industry 40 per cent, and colleges and other nonprofit institutions 4 per cent. ${ }^{19}$ Of the total research and development activities performed by industry, it is estimated that government will finance 45 per cent and industry 55 per cent. The estimated slight increase in the share financed by industry is based on the assumptions that (1) diplomacy will reduce the intense arms race which has characterized the past decade, and (2) industry will increase its outlays on fundamental (basic) research. But even under these rather optimistic assumptions less than onehalf of total inventive activity would be governed by the traditional private incentives and public instruments of control in 1969. The already perceptible decline in the relative importance of those incentives and the correspondingly larger role played by the budgetary process can therefore scarcely be viewed as mid-twentieth century ephemera.

\section{Inventive Activity, Incentives, and Public Policy}

\section{THE PATENT SYSTEM}

Public policy toward inventive activity in the United States can be dated from the Constitution of 1787 , which gave Congress the power "to promote the progress of Science and useful Arts, by securing for limited times to Authors and Inventors the exclusive Right to their respective Writings and Discoveries." Congress exercised that power in 1790 by enacting a law establishing a patent system, which was to be virtually the sole instrument of public policy on inventions until

\footnotetext{
${ }^{18}$ The author emphasizes the word "governs" and urges that it not be confused with "induces." How much inventive activity the patent system induces is taken up later on.

${ }^{10}$ Dexter M. Keezer, Douglas Greenwald, and Robert Ulin, "The Outlook for Expenditures on Research and Development During the Next Decade," American Economic Review, May 1960, p. 355.
} 
the enactment of the Sherman Act a century later, ${ }^{20}$ and the primary instrument until it became eclipsed by the budgetary process at the outset of World War II. It is still the principal instrument of public policy toward inventive activity financed and performed by private industry although, as will be shown later, the patent system has itself been governed in no small way by antitrust policy.

While the rationale of patent systems varies from country to country ${ }^{21}$ - and even from time to time within each country-most students of the United States patent system appear to agree that it finds its principal justification in terms of the following premises.

1. Prospective rewards to the inventor during the seventeen-year period of protection will often exceed the costs of research, adaptation, and disclosure. The prospective rewards would exceed such costs in fewer cases were the seventeen-year property right not granted. Hence, the patent system induces inventive activity which would not otherwise be undertaken. Stated differently, in the absence of patent protection the social benefits of inventive activity often exceed the private rewards; the patent system is designed to narrow the difference.

2. Prospective gains to society in the form of new products, processes, and disclosed knowledge the patent system encourages exceeds the social costs of the seventeen-year monopoly grant.

It is in terms of these two premises that the patent system, as distinct from abuses of the system, must be assessed. If the system accounts for a net increase in inventions having a value to society exceeding the costs society pays for them, the patent system is justifiable in economic terms. It is worth pointing out that fulfillment of this condition justifies the system irrespective of how much inventive activity the system encourages, provided the costs of maintaining the system itself is included among the costs society incurs. In this sense the patent system is not unlike any other incentive-creating public policy, for example, a change in interest rates by the monetary authorities. Conceptually, the system performs optimally if it produces marginal social benefits equal to the marginal social costs it imposes, irrespective of the level of activity at which this equality occurs.

Most of the thoughtful views expressed on the patent system-of

${ }^{\text {s0 }}$ Exceptions, as already pointed out, were the federal government's early research activities in agriculture and defense, which until 1940 accounted for a small part of total research.

${ }^{21}$ For an excellent discussion of this question see Fritz Machlup, An Economic Review of the Patent System, study of the Subcommittee on Patents, Trademarks, and Copyrights of the Senate Committee on the Judiciary, 85th Cong. 2nd sess., 1958, pp. $20 \mathrm{ff}$. 
which there are many-have not been especially relevant to an appraisal of the system in terms of these criteria. Those who apparently accept the system as it presently exists lean heavily on the logical appeal of the proposition that patent protection is necessary to induce inventive activity and the requisite investment to exploit it commercially. ${ }^{22}$ Few economists who subscribe to this view regard the patent system as an unmixed blessing, and some approve its retention only because no superior substitute has yet been offered. ${ }^{23}$ It is emphasized, however, that this position finds its principal support in the intuitive appeal of the a priori logic of the case rather than in any empirical proof of the premises on which the case rests.

This does not mean that there is no factual information on how the patent system affects inventive effort, but rather that the existing facts scarcely add up to a reliable empirical test of the important hypothesis. Several industry studies have developed persuasive evidence that the patent system has promoted technological progress in selected industries, often by making possible the entry of new firms to compete with established, and patent protected, processes and products. ${ }^{24}$ And at least one recent study offers evidence that business men regard the patent system as an important stimulus to research by their respective companies and, because of the disclosure requirement, to the growth in usable knowledge and a reduction in wasteful duplication of research effort. ${ }^{25}$ While all these studies point in the direction of the idea that firms undertake research when the resulting discoveries may be patented (which they would not otherwise undertake), and that the disclosure requirement enhances both the level and exchange of patentable knowledge, the studies have developed

${ }^{22}$ See especially citations of J. B. Clark, A. T. Hadley, Irving Fisher, Ludwig von Mises, John Jewkes, F. W. Taussig, A. F. Ravenshear, F. von Weiser, and A. C. Pigou in Fritz Machlup, op. cit., pp. 33-40.

${ }^{23}$ See John Jewkes, David Sawers, and Richard Stillerman, The Sources of Invention, London, Macmillan, 1958, pp. 251-253.

${ }^{24}$ See W. Rupert Maclaurin, Invention and Innovation in the Radio Industry, New York, 1949; Arthur A. Bright, Jr., The Electric-Lamp Industry: Technological Change and Economic Development from 1800 to 1947, New York, 1949; Harold C. Passer, The Electrical Manufacturers, 1875-1900: A Study in Competition, Entrepreneurship, Technical Change and Economic Growth, Harvard University Press, 1953; and in Patent, Trademark, and Copyright Journal of Research and Education, June 1957: Nathan Belfer and Irving H. Siegel, "Patent and Other Factors in the Development of Firms in the Custom HeatTreating Industry," pp. 57-73; and Weldon Welfing and Irving H. Siegel, "Patent and Other Factors in the Growth of the Electronics Industry in the Boston Area," pp. 119-126.

${ }^{25}$ Jesse W. Markham, James S. Worley, and Dwight S. Brothers, "The Value of the American Patent System: An Inquiry into Possible Approaches to Its Measurement," Patent, Trademark, and Copyright Journal, June 1957, pp. 20-56. 
relatively little information on the social costs at which these positive benefits of the patent system are obtained.

Critics of the patent system have tended to direct their attack toward the system's "abuse," and have only incidentally questioned the system's logical basis. Hence, much criticism of the system envisages the policy remedy of patent reform rather than the more drastic remedies of outlawing the system altogether or replacing it with another set of incentives and controls. The reasons generally advanced for calling in question the premises on which the patent system rests may be summarized as follows: ${ }^{26}$

1. The patent system was designed for the individual inventor, but over the years research has become concentrated in the large corporation. This shift in location of inventive activity has rendered the patent system obsolete.

2. The rise of institutional research-notably government, nonprofit organization, and institutionalized corporate research-has rendered the patent system inapplicable to a large portion of inventive activity.

3. Interfirm competition has become the primary stimulus to inventive activity; the patent system is therefore no longer necessary.

4. The rise of monopoly has provided the business firm with sufficient means of protection without resorting to patenting.

5. The purely formal test for the novelty of an invention has encouraged the inventor, especially the large corporation, to keep many important aspects of an invention secret. Further, to avoid impairing the novelty of possible future patent claims, business firms refrain from publishing scientific discoveries. In these ways the patent system encourages secrecy rather than the publication of knowledge.

6. In an age characterized by publicity and efficient communications it is impossible to keep important scientific discoveries secret. Hence, under a patent system, society trades valuable monopoly grants for information which it could get for nothing.

These six objections to the patent system are neither mutually

${ }^{26}$ These criticisms, in slightly different language, may be found in the following references: Sir Arnold Plant, "The Economic Theory Concerning Patents for Inventions," Economica (new series), 1934, pp. 44-46; Michael Polanyi, "Patent Reform," Review of Economic Studies, 1944, p. 71 ; Alfred E. Kahn, "Deficiencies of American Patent Law," American Economic Review, 1940, p. 479; Seymour Melman, The Impact of the Patent System on Research, study of the Subcommittee on Patents, Trademarks, and Copyrights of the Senate Committee on the Judiciary, 85th Cong. 2nd sess., pp. 8, 18;S. C. Gilfillan, "The Prediction of Technical Change," Review of Economics and Statistics, November 1952, pp. 376-377; and Machlup, op. cit., pp. 28-52. 
exclusive nor internally consistent. In some cases conclusions follow from unsupportable premises, and some observations which may be factually true do not negate the traditional rationale for the patent system. For example 5 and 6 obviously are inconsistent; if one is true the other must be false. To a lesser extent so are 3 and 4 : if it can be stated as a general proposition that inventive activity is the primary means of interfirm competition, it is difficult to see how protected monopolistic positions have rendered unnecessary the additional protection the patent system affords. A world of firms vigorously competing through innovations and one made up of firms with monopoly power insulated from competitive forces obviously are two different worlds. Moreover, although the prevailing level oi monopoly power may exceed that consistent with a competitively regulated economy, there is no persuasive evidence that it has risen perceptibly over the past half-century. ${ }^{27}$ It is probably true for a variety of reasons-one of which was dealt with at length in the preceding section-that a smaller proportion of inventive activity is governed by the patent system than was the case in earlier years. However, the justification for the system as an instrument of public policy does not lie in the share of total inventive activity it governs.

Since almost all those who question the logical basis of the patent system have either explicitly or implicitly based their conclusions on historical changes in industrial organization, it is essential to inquire into how these changes may have altered the relative social benefits and social costs of the system.

Corporate enterprise has undoubtedly displaced the solo inventor as the primary performer of inventive activity. ${ }^{28}$ It does not clearly follow from this, however, that the social costs of the patent system have increased relative to its social benefits. Uncertainty, it is generally agreed, ${ }^{29}$ is the essential characteristic of inventive activity. A traditional rationale for the patent system is that, by holding out the possibility of greater rewards for inventive activity that turns out to be commercially successful, it encourages inventors to incur the costs of uncertainty. Corporate enterprise obviously has not eliminated the risks of uncertainty, as is sometimes claimed, but has simply transferred them from the individual scientist-now largely, an

${ }^{27}$ See G. Warren Nutter, The Extent of Enterprise Monopoly in the United States, University of Chicago Press, 1952.

${ }^{28}$ See footnote 13, supra.

${ }^{29}$ Cf. Charles J. Hitch, "Research and Development and the Economy," in Nationa] Science Foundation, Proceedings, op. cit., p. 132. 
employable factor-to the corporation itself. However, in at least one way the rise of the large corporate research laboratory has reduced uncertainty. The outcome of any one of the several dozen research projects a large corporation may launch in a given time period may be as uncertain now as it would have been fifty years ago, but it may be relatively certain that at least one or two will turn out to be commercial successes. Hence, the large corporate laboratory can, on the insurance principle, reduce uncertainty through greater coverage and larger numbers and, accordingly, can predict with greater reliability the probable returns on its research outlays. But the expected returns are themselves enhanced by the possibility of patent protection. Hence, if it can be assumed that the marginal costs of inventive activity turn upward at some point, it can be concluded that the patent system stimulates some research that private firms otherwise would not undertake-presumably the more costly and more uncertain projects.

The statistical evidence, while far from satisfactory, suggests either that the research required to produce a patentable invention, or that the research which does not lead to patents, increased substantially over the past half-century. It probably suggests a combination of both. In 1900 one patent was issued for every 1.7 scientists and engineers in the United States; in 1954 one patent was issued for every 20.5 scientists and engineers. ${ }^{30}$ Research outlays by business firms have increased, especially since 1930 , more rapidly than the population of scientists and engineers. Hence, the scientific manpower and dollar costs per patentable invention or nonpatentable inventive effort, or both, have increased enormously. ${ }^{31}$ Much of the high-cost research characterized by uncertainty may have been stimulated by the patent system; much of the research that was directed toward small product and process innovations led to relatively few patents and probably would have occurred in the absence of the patent system. The absolute decline in recent years in the number of patents issued while research

${ }^{30}$ Melman, op. cit., p. 29. Melman infers from these data that the patent system is no longer justified, or not as much justified as it once was.

${ }^{31}$ The rate of patenting in industry groups relating to the mechanical and industrial arts has declined while that in industry groups relating to chemistry and physics has increased. Cf. Alfred B. Stafford, "Trends of Invention in Material Culture: A Statistical Study of the Class-wise Distribution of Inventive Effort in the United States as Determined by Patents Granted During the Period 1914-1945," unpublished Ph.D. thesis, University of Chicago, 1950. This shift may have accounted for a portion of the increase in research costs per patentable invention. 
outlays in the private sector registered large increases is consistent with this interpretation. ${ }^{32}$

It is highly improbable that a single inflexible patent system can apply optimally both to costly research contemplating major technological breakthroughs and to competitive research aimed at maintaining or strengthening a firm's market position in an established product line. The existence of these two broad classes of inventive activity suggests the advisability of a dual patent system, in principle analogous to the familiar rationale for price discrimination. The system would provide for relatively long periods of protection for major technological breakthroughs, because they are of high value and involve uncertainty and large research costs. It would also provide for much shorter-term protection for inventive effort generally considered to be an integral part of dynamic competition, and productive of incremental changes no one of which adds substantially to society's total stock of knowledge. Such a dual system would no doubt more nearly equate the marginal social costs of both classes of inventive activity with their corresponding marginal social rewards and, however great the administrative difficulties, would go a long way toward resolving important inconsistencies and conflicts in public policy-especially those existing between patent and antitrust policies.

\section{ANTITRUST POLICY AND THE PATENT SYSTEM}

The insulation from the forces of competitive imitation the patent system provides may raise no special problem and extract no unusual social cost in economies where public policy regards monopoly as neutral, or possibly even as desirable. But under United States antitrust policy the patent laws give to firms a protection from competitive forces they cannot themselves erect with impunity. In short, it is primarily because of antitrust policy that the protection the patent system provides can be regarded as a serious social cost. In the language of the late Joseph A. Schumpeter, such protection may be necessary to induce those innovations which strike "not at the margins of the profits and the outputs of the existing firms but at their foundations and their very lives." 33 But to accord the same protection to innova-

32 Throughout the 1930's annual average patent increases amounted to 48,520; in 1954 patent increases amounted to only 33,872 (Melman, op. cit., p. 29). However, data issued by the United States Patent Office since this paper was first written show that patent increases in 1958 reached 48,405 .

${ }_{39}$ Capitalism, Socialism, and Democracy, 2nd ed., New York, Harper, 1947, p. 84. Those who may be tempted to invoke the authority of Schumpeter in defense of liberal use of patent protection will meet with disappointment. Although Schumpeter defined 
tions of a much lower order, and which may result from the normal course of vigorous interfirm competition in existing markets, compromises unnecessarily the principles of antitrust policy. ${ }^{34}$

Early United States patent policy logically surrounded the patent with what at that time were considered to be effective safeguards: exclusive use was limited to fourteen years; the patent applicant was required to specify exactly what he claimed to have discovered and fully to disclose it; and patents were to be issued only for technological devices sufficiently useful and important to merit the reward of limited exclusive use. ${ }^{35}$ Statutory safeguards were further strengthened by the institutional environment to which they were addressed. In 1790 invention was almost entirely a matter of individual tinkering within the area of the mechanical arts. Limitations on the individual's inventive genius and financial resources assured society that no one person alone could monopolize an industry through patenting or patent accumulation.

In the hundred years that separated the first patent statute and the Sherman Act-and for a decade or two thereafter-these safeguards were substantially weakened by legislative revision, administrative procedures, judicial interpretation, and unchecked abuse of the system by private parties. In 1861 Congress lengthened the period of exclusive use from fourteen to seventeen years, and through other statutory amendments over the years enlarged the area of patent coverage. In an 1817 case Justice Story construed "useful" to mean any invention not "mischievous" or "immoral." ${ }^{36}$ The Patent Office adopted procedures which encouraged both the proliferation and abuse of patent rights. ${ }^{37}$ Business firms adjusted their practices to the weaker safeguards and, as an impressive list of court cases shows, often overstepped the liberal legal boundaries. Two students of the problem, summing up the situation as it existed in the first decade of the twentieth century, stated that "... the patent system had become a special sanctuary for trusts, pools, and trade confederacies." 38 Another observed that "... the

innovation as any alteration of existing production functions, his empirical observations were confined almost entirely to those that brought on revolutionary changes, e.g., the automobile, rayon, the chemical industries, and so on. These appear to be the innovations he had in mind when he sought to justify temporary protection by private and public means.

${ }^{34}$ This conflict between the patent right and antitrust policy is evidently being resolved more and more in favor of antitrust; see below.

${ }^{\text {ss }}$ See George W. Stocking and Myron W. Watkins, Monopoly and Free Enterprise, New York, Twentieth Century Fund, 1951, pp. 450-452.

${ }^{38}$ Lowell v. Lewis, 15 Fed. Cases 1018 (1817), p. 1019.

${ }^{37}$ Stocking and Watkins, op. cit., pp. 455-456, 58-59.

${ }^{\text {so }}$ Ibid., p. 454. 
protection of patent franchises had enabled big business to circumvent the basic law prohibiting monopoly." ${ }^{39}$ These pronouncements probably exemplify the more extreme diagnosis but they are backed by serious and responsible studies which make it clear that the patent system, if left unchecked by a vigorous antitrust policy, can be made an effective vehicle for the spread of monopoly power. Until 1890, indeed until several decades thereafter, antitrust policy was something less than effective. In consequence, the social cost of the patent system unquestionably was enhanced, and no doubt some would argue that the social rewards of the system were reduced.

Over the past three or so decades an unpublicized but discernible trend has developed toward resolving conflicts between the past lax patent policy and the recent relatively vigorous antitrust policy in favor of the latter. Evidence of this trend is found in myriad sources, but its specific content is more readily identifiable in selected court cases. Decisions arising out of such cases have tended to (1) curtail extension of the effects of the patent beyond the invention described in the patent claim; (2) establish higher standards for patentable inventions; and (3) prescribe compulsory licensing-sometimes royalty-free licensing —of patents used, and abused, to further monopoly power.

In 1912 the Supreme Court approved in the A. B. Dick case a restriction the patentee imposed on an unpatented material used in the patented device. ${ }^{40}$ It expressly withdrew this approval in the Motion Pictures Patent case ${ }^{41}$ in 1917; in a series of cases decided in the 1940's the Court established doctrines that the licenses could not fix the prices of unpatented products produced by patented processes or machines or where only a part of the product is patented $;{ }^{42}$ and in 1948 struck down a royalty provision based on the sale of an unpatented as well as a patented commodity as an illegal price-fixing device. $^{43}$

Unless they result in industrywide price fixing, price restrictions imposed by the patentee on the licensee are generally held, as in the General Electric case, to be legal on the grounds that they are "nor-

${ }^{39}$ Walton H. Hamilton, Patents and Free Enterprise, TNEC Monograph No. 31, Washington, 1941, p. 62.

${ }^{40}$ Henry v. A. B. Dick Co., 224 U.S.-1-(1912).

${ }^{41}$ Motion Picture Patents Co. v. Universal Film Mfg. Co., 243 U.S.-502, 510 (1917).

${ }^{42}$ See Report of the Attorney General's National Committee to Study the Antitrust Laws, Washington, 1955, p. 234.

${ }^{43}$ United States v. United States Gypsum Co., 333 U.S. 364, 384-385 (1948). 
mally and reasonably adapted to secure pecuniary reward for the patentee's monopoly." ${ }^{44}$ In recent years considerable effort has been exerted to overturn this doctrine. In the Lime Material decision ${ }^{45}$ the failure to obtain a majority of the Supreme Court resulted in neither affirming nor overruling General Electric. However, a district court found illegal the particular price-fixing license before it in Newburgh Moire Co. v. Superior Moire Co. in $1952 .{ }^{46}$ Several members of the Attorney General's National Committee to Study the Antitrust Laws argued strongly that such price-fixing clauses not only should be proscribed, but in fact have been proscribed in more recent Supreme Court interpretations of the scope of patent rights. ${ }^{47}$ And in a series of decisions beginning in 1942 the Court overturned a long-standing rule of patent law to the effect that a licensee is not free to contest the validity of the licensed patent. In these decisions the Court held that the licensee did not forego this freedom where the license included a price-fixing clause. ${ }^{48}$

In the last three decades the mortality rate for patents before the various courts has substantially increased. It is not entirely clear whether the increase in invalidations is attributable to a relaxation of standards at the Patent Office or to a stiffening of the standards used by the courts; however, most evidence supports the view that the courts have begun to set higher standards of patentability-a view the courts themselves seem to share. ${ }^{49}$ It would appear that Congress has also imposed higher standards on the patent applicant. The test set forth in the early patent statutes was whether the discovery was "new and useful-or a new and useful improvement thereon not known or used before." In Hotchkiss v. Greenwood the Supreme Court had added the additional criterion that "an improvement in the prior art must involve more ingenuity and skill than would be obvious to an ordinary mechanic in the art." ${ }^{50}$ Congress appears to have approved this test in the Patent Act of 1952:51

${ }^{44}$ United States v. General Electric Co., 272 U.S. 476 (1926).

${ }^{45}$ United States v. Lime Material Co., 333 U.S. 287 (1948).

46105 F. Supp. 372. (D.N.J. 1952).

47 Report of the Attorney General's National Committee to Study the Antitrust Laws, pp. 235-236.

48 Ibid., p. 234 at n. 49.

${ }^{40}$ See Gay Chin, "The Statutory Standard of Invention: Section 103 of the 1952 Patent Act," Patent, Trademark, and Copyright Journal of Research and Education, Fall 1959, pp. 317-329, especially p. 318 .

${ }^{50}$ Ibid., citing 52 U.S. 247 (1850).

5135 U.S.C. 103. The courts appear to be divided on whether this higher legislative test is as high as that the courts themselves have established (see Chin, op. cit., pp. 320-323). 
A patent may not be obtained-if the differences between the subject matter sought to be patented and the prior art are such that the subject matter as a whole would have been obvious at the time the invention was made to a person having ordinary skill in the art to which said subject matter pertains.

The courts have also shown a decided tendency in recent years to deny the patentee exclusive use where it results in significant monopoly power. According to S. Chesterfield Oppenheim, between 1941 and 1957 over 100 judgments, involving more than 300 antitrust defendants, provided for compulsory licensing or the outright dedication of as many as 35,000 patents. ${ }^{52}$ Because many of these were consent judgments the judicial rationale for the trend toward compulsory licensing and dedication of patents must be inferred from a small number of decisions. However, in a few cases the courts have spoken with clarity. In the United Shoe Machinery case Judge Wyzanski stated $:^{53}$

Defendant is not being punished for abusive practices respecting patents, for it engaged in none, ... It is being required to reduce the monopoly power it has, not as a result of patents, but as a result of business practices. And compulsory licensing, on a reasonable royalty basis, is in effect a partial dissolution on a non-confiscatory basis . . .

Judge Forman in ordering dedication of certain patents in the General Electric case stated $:^{54}$

In view of the fact that General Electric achieved its dominant position in the industry and maintained it in great measure by its extension of patent control the requirement that it contribute its existing patents to the public is only a justified dilution of that control made necessary in the interest of free competition in the industry.

In the 1956 A. T. \& T. consent decree ${ }^{55}$ all the patents owned by defendents A. T. \& T. and Western Electric Company were made subject

${ }^{32}$ Patent, Trademark, and Copyright Journal, June 1957, pp. 135-136.

s3 110 F. Supp. 295, 351 (D. Mass. 1953), aff'd. per curiam 374 U.S. 521 (1954).

s4 115 F. Supp. 835 (D.N.J. 1953).

${ }^{55}$ United States v. Western Electric Inc., civil action 17-49 (D.N.J.), decree entered January $24,1956$. 
to compulsory licensing to all domestic applicants, and about 8,600 patents involved in licence exchange agreements with three other large electronic companies were made subject to royalty-free compulsory licenses. The decree was hailed as "a sweeping patent victory" that "will open up the electronics and television industry to competition."

These are a few of the recent compulsory licensing and patent dedication decrees based almost entirely on antitrust considerations. In others, the issues of patent abuse and monopoly have often been intertwined, but the resulting decrees have generally contemplated remedies of the sort antitrust policy envisages; see, for example, the 1952 I. C. I. decree. ${ }^{57}$ This is a discernible break with traditional patent adjudication, where relief usually consisted of an injunction against the enforcement of patent licenses used to effectuate monopolistic control. ${ }^{58}$

The constraints antitrust policy has placed on patent usage are of relatively recent origin and reflect the increased vigor of antitrust law administration over the past two decades. ${ }^{59}$ In view of what is known and, more importantly, what is not known about the operation of the patent system, a strong argument can be made for assigning this role to antitrust policy. The principle social costs of the patent system are the temporary monopoly positions to which it gives legal protection. Antitrust policy has provided the traditional means for mitigating the excesses of monopoly to which such costs are attributable.

\section{Summary}

In the past two decades two significant developments have brought about fundamental changes in the institutional environment of inventive activity in the United States. (1) the share of total research and development expenditures financed by government rose from 13 per cent to a staggering 60 per cent; and (2) antitrust policy was strengthened and administered with increasing vigor. A concomitant of the first was a large-scale substitution of the budgetary process for the

so Business Week, January 28, 1956, p. 160.

${ }^{57}$ United States v. Imperial Chemical Industries, 105 F. Supp. 215, 222 (S.D.N.Y. 1952).

${ }^{58}$ Cf. "Compulsory Licensing by Antitrust Decree," Yale Law Journal, 1946, pp. 77-81 .

${ }^{60}$ There is little doubt that the trend since the late 1930's has been toward a more vigorous antitrust policy. See Edward S. Mason, Economic Concentration and the Monopoly Problem, Harvard University Press, 1957, p. 400; Jesse W. Markham, "United States Antitrust Po!icies: How Effective Have They Been?" Southern Economic Journal, July 1959, p. 61. 
private profit incentive and the patent system as a means of governing inventive activity. The second led to resolution of conflicts between traditional patent policy and recent antitrust policy in favor of the latter. Accordingly, the patent right has become relatively less important, and the protection it affords less absolute, than it once was. While these developments have not rendered obsolete the historical debate over the merits of the patent system they have clearly made it less compelling.

The ascendency of government in inventive activity may be largely explained in terms of national defense requirements, but the impact of the research it sponsors is felt throughout the economy generally. Just as the peaceful tin can may be drafted for war, so may atomic energy, missile science, space photography, electronic computors, and so on, be turned to peaceful purposes. The fundamental laws of nature, and many of their applications, are unaffected by the state of politics. With well over one-half of total inventive activity subject to government control the budgetary process assumes paramount importance. In a large area it has supplanted the traditional economic incentives to invent. The economic and political considerations integral to the budgetary process will play a major role in shaping the course of inventive activity in the forseeable future. What these considerations are and how they may be assimilated in welfare economics should be an interesting and challenging subject for the political economist. 